\title{
VIRTUAL POINTER UNTUK IDENTIFIKASI ISYARAT TANGAN SEBAGAI PENGENDALI GERAKAN ROBOT SECARA REAL-TIME
}

\author{
M. Isa Irawan ${ }^{1}$, dan Edi Satriyanto ${ }^{2}$ \\ ${ }^{1}$ Bidang Ilmu Komputer- jur. Matematika FMIPA - ITS, \\ ${ }^{2}$ Politeknik Elektronika Negeri Surabaya (PENS) \\ E-mail: mii@its.ac.id ${ }^{1}$, edi@eepis-its.edu ${ }^{2}$
}

\begin{abstract}
ABSTRAK: Banyak penelitian sebelumnya berrhubungan dengan human robot interface, interaksi manusia dengan robot menggunakan isyarat tangan sebagai bahasa tubuh manusia. Isyarat tangan yang digunakan dalam penelitian ini adalah isyarat tangan bergerak yang berposisi menunjuk untuk identifikasi isyarat tangan, faktor yang paling penting adalah kemampuan membedakan tangan dengan obyek lain berdasarkan warna kulitnya. Metode untuk mendeteksi warna kulit tangan adalah Fuzzy C-Means (FCM) yang memiliki kemampuan memperbaiki pusat cluster dan nilai keanggotaan tiap data secara berulang dengan meminimumkan fungsi obyektif, sehingga pusat cluster akan bergerak menuju lokasi yang tepat. Hasil pengenalan dengan metode moving detection, mampu mendeteksi pergerakan obyek bergerak. secara baik sebesar 91.07944\% dalam 1 detik. obyek Skin detection dengan Fuzzy C-Means (FCM) mampu melakukan segmentasi warna kulit dan bukan kulit secara real-time dengan tingkat keberhasilan. $90.2834 \%$ Identifikasi pola isyarat tangan dengan rule base tingkat keberhasilannya $86.67 \%$. Identifikasi hasil virtual hand writing menggunakan jaringan syaraf tiruan metode LVQ sebagai perintah untuk mengendalikan robot tingkat keberhasilannya mencapai $79.2 \%$.
\end{abstract}

Kata kunci: virtual pointer , Fuzzy C-Mean (FCM), jaringan syaraf tiruan LVQ

\begin{abstract}
Many previous researches have been done in relation to human-robot interface, which is an interaction between human and robot using hand gesture. Hand gesture that is used in this research is a moving hand gesture with pointing position. The most important factor to identify hand gesture is the ability to differentiate hands with other objects based on the skin colour. A method to detect hand skin colour is using Fuzzy C-Means (FCM) which can refine a cluster centre and the membership value of each data iteratively by minimizing objective function. Hence, the cluster centre moves to the correct location. Recognition result with moving detection method was able to detect the movement of a moving object $91.07944 \%$ in 1 second. Skin detection using FCM was able to segment skin colour and not the skin in real time with the successful rate $90.2834 \%$. The successful rate of the hand gesture pattern identification using rule base is $86.67 \%$. The successful rate of virtual hand writing using LVQ artificial neural network as a command for controlling a robot is $79.2 \%$.
\end{abstract}

Keywords: virtual pointer, Fuzzy C-Mean (FCM), artificial neural network LVQ

\section{PENDAHULUAN}

Salah satu alat komunikasi manusia adalah menggunakan isyarat tangan. Untuk tuna wicara misalnya, isyarat tangan sebagai alat komunikasi utama untuk bisa berinteraksi sehari-hari sebagai media komunikasi [1]. Isyarat tangan juga banyak digunakan sebagai kode isyarat atau sandi untuk mengirim berita atau sebagai system pengaturan seperti dalam sistem parkir pesawat terbang $[2,3]$, ada rambu-rambu dari isyarat tangan, begitu pula polisi dalam mengatur lalu lintas, dan masih banyak lagi [4, $5,6]$.

Tracking gerakan dan isyarat tangan oleh komputer dapat digunakan sebagai suatu dasar pengem- bangan teknologi robotika [7]. Suatu interface virtual mouse berbasis gambar (vision) secara real time merupakan suatu metode yang dapat mewakili tracking tersebut $[8,9]$. Dukungan user interface diantara perangkat yang lain akan memudahkan pengendalian yang smooth dari pointer mouse dalam jarak jauh secara real time [10].

Berdasarkan hal tersebut, maka dalam penelitian ini dilakukan pengembangan sistem agar komputer bisa berinteraksi dengan manusia berdasarkan isyarat tangan yang bergerak, bukan pola tangan yang diam. Komputer harus terlebih dahulu memahami isyarat tangan manusia sebagai simbol-simbol yang telah ditentukan sebagai pengendali bagi suatu robot model laboratorium, sehingga dibutuhkan pengolahan citra 
sebagai pembelajaran pola isyarat tangan yang berupa citra tangan dan nantinya digunakan sebagai serangkaian informasi bahasa isyarat sebagai pengendali robot. Indentifikasi isyarat tangan dilakukan secara real-time, sehingga pertama-tama dibutuhkan metode untuk mendeteksi obyek yang bergerak, akan tetapi obyek yang bergerak tidak hanya tangan sehingga harus diidentifikasi bentuk tangan. Membedakan tangan dan bukan tangan yang harus dilakukan adalah deteksi warna kulit tangan terlebih dahulu menggunakan Fuzzy C-Means [11] untuk clustering warna kulit tangan. Sedangkan pola bentuk tangan dapat digunakan integral proyeksi untuk menentukan bentuk pola tangan sebagai bahasa isyarat yang telah ditentukan. Pergerakan identifikasi isyarat tangan akan menghasilkan suatu bentuk isyarat tangan yang disusun dalam bentuk gambar angka (virtual hand wirting) sehingga hasil gambar angka tersebut bisa digunakan untuk mengendalikan robot baik dalam jarak dekat maupun jauh.

\section{PERANCANGAN SISTEM}

Perancangan dan pembuatan sistem identifikasi isyarat tangan sebagai pengendali telerobotik secara real-time dalam penelitian ini adalah sebagai berikut.

\section{Konfigurasi Sistem}

Dalam penelitian ini digunakan web-cam untuk menangkap gambar secara on-line yang dihubungkan dengan komputer. Sebelumnya web-cam harus memperhatikan intensitas pencahayaan ruangan sehingga warna obyek sesuai dengan warna sebenarnya. Obyek yang ditangkap oleh kamera obyek bergerak, selain obyek diam. Dalam penelitian ini, obyek yang bergerak harus mampu diidentifikasi pergerakannya, dengan membandingkan data piksel-piksel tetangganya. Obyek yang bergerak yang digunakan dalam penelitian ini adalah obyek tangan. Pertama-tama yang harus dilakukan adalah mendeteksi warna kulit tangan dengan menggunakan Fuzzy C-Means(FCM). Keberhasilan deteksi warna kulit sangat penting karena sebagai dasar untuk mengetahui pola tangan yang digunakan untuk melakukan pergerakan tangan yang akan menghasilkan pola angka 1 sampai 6 sebagai perintah pngendali robot secara jarak jauh. Ekstraksi ciri pola tangan menggunakan integral proyeksi, hasil ekstraksi dan training diperoleh batasan nilai minimum dan maksimum dari pola tangan menunjuk yang merupakan bentuk tangan yang digunakan dalam penelitian ini. Sehingga dengan rule-base [12], pola tangan menunjuk dapat diidentifikasi sesuai dengan kriteria berdasarkan hasil training yang telah digunakan. Hasil pergerakan tangan yang telah identifikasi menghasilkan pola angka 1 sampai 6, pola angka tersebut diidentifikasi dengan menggunakan LVQ salah satu dari metode neural network [5], hasil identifikasi pola angka tersebut sebagai perintah gerakan robot sesuai dengan perintah angka 1 sampai 6 . Gambar 1 adalah blok diagram identifikasi dari penelitian ini.

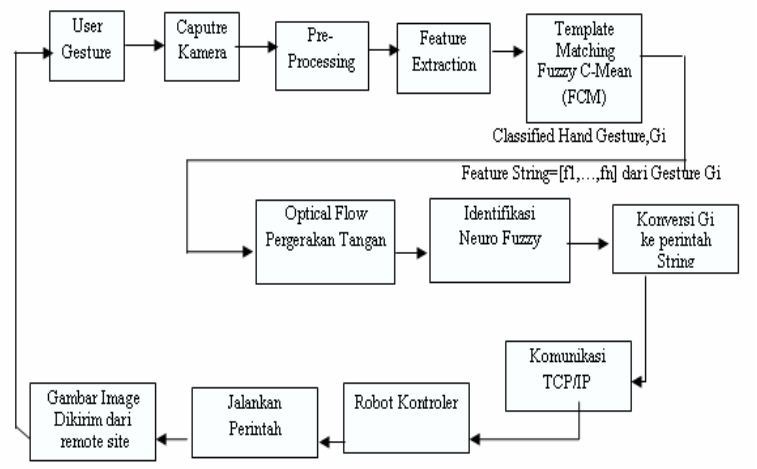

\section{Gambar 1. Blok Diagram Identifikasi Isyarat} Tangan

Gambar 1 merupakan blok diagram dari sistem identifikasi isyarat tangan sebagai pengendali telerobotik secara real-time. Dalam penelitian ini, selain membuat software identifikasi isyarat tangan secara real-time yang merupakan human computer interface juga digunakan hardware robot tangan yang telah dimodifikasi sehingga siap menerima perintah sesuai dengan tujuan dalam penelitian ini.

Peralatan yang digunakan dalam penelitian ini adalah:

- sebuah laptop pentium IV yang dilengkapi Sistem Operasi Window XP

- bahasa pemrograman VB 6.0

- sebuah robot tangan Lynxmotion RIOS SSC-32 V1.01

- interface DAC berfungsi untuk menterjemahkan perintah komputer menjadi gerakan tangan robot

\section{Deteksi Pergerakan (Moving Detection)}

Penelitian ini menggunakan obyek yang bergerak. Obyek yang bergerak harus mampu terdeteksi pergerakaannya. Metode yang digunakan untuk mendeteksi pergerakan adalah menggunakan algoritma komputasi dengan membandingkan perbedaan antara data piksel yang lalu dengan data piksel tetangganya pada t waktu.

\section{Fuzzy C-Means (FCM)}

Obyek yang bergerak dalam penelitian ini adalah ujung telunjuk tangan. Untuk mengidentifikasi tangan 
maka harus dilakukan pengenalan warna kulit tangan yang merupakan dasar dari pengenalan pola tangan menunjuk. Yang akan dikerjakan oleh sistem adalah melakukan pengelompokan jenis warna-warna kulit yang menjadi target warna tangan yang akan diidentifikasi bentuk pola tangannya. Karakteristik pengelompokan ini memerlukan suatu metode yang punya tidak terlalu kaku dalam mengclusterkan data hasil pengenalan, karenanya dipilihlah metode Fuzzy $C$ Means (FCM). FCM yang memiliki kemampuan memperbaiki pusat cluster dan nilai keanggotaan tiap data secara berulang dengan meminimumkan fungsi obyektif, sehingga pusat cluster akan bergerak menuju lokasi yang tepat.

FCM adalah suatu teknik pengclusteran data yang mana keberadaan tiap tiap data dalam suatu cluster ditentukan dalam nilai keanggotaan. Metode ini pertama kali diperkenalkan oleh Jim Bezdek pada tahun 1981 [13]. Konsep dasar FCM pertama kali adalah menentukan pusat cluster pada kondisi awal pusat cluster ini masih belum akurat. Setiap data memiliki derajat keanggotaan untuk tiap tiap cluster dengan cara memperbaiki pusat cluster dan nilai keanggotaan tiap data secara berulang, maka akan dapat dilihat bahwa pusat cluster akan bergerak menuju lokasi yang tepat. Perulangan ini didasarkan pada minimisasi fungsi obyektif.

Algoritma FCM diberikan sebagai berikut [11]:

1. Tentukan :Input data yang akan dicluster $\mathrm{X}$, berupa matriks berukuran $\mathrm{n} \times \mathrm{m}$, dengan $\mathrm{n}=$ jumlah data yang akan dicluster; $m=$ jumlah atribut setiap data dan $X_{\mathrm{ij}}=$ data sampel ke-i $(\mathrm{i}=1,2, \ldots$, $n)$, atribut ke-j $(j=1,2, \ldots, m)$

2. Tentukan
a. Jumlah cluster yang akan dibentuk $=\mathrm{c}(\geq 2)$
b. Pangkat $($ pembobot $)=\mathrm{w}(>1)$
c. Maksimum iterasi=MaxIter
d. Kriteria penghentian $=\xi$ (nilai positif yang sangat kecil)
e. Iterasi awal , $t=1$

3. Bangkitkan bilangan random $\mu_{i k}, \mathrm{i}=1,2, \ldots, \mathrm{n} ; \mathrm{k}$ $=1,2, \ldots, \mathrm{c}$; sebagai elemen-elemen matriks partisi awal U. Hitung jumlah setiap kolom (atribut):

$Q_{j}=\sum_{k=1}^{c} \mu_{j k}$

dengan $\mathrm{j}=1,2, \ldots, \mathrm{m}$

Hitung :

$\mu_{i k}=\frac{\mu_{i k}}{Q_{j}}$
4. Hitung pusat cluster ke-k: $\mathrm{V}_{\mathrm{kj}}$ dengan $\mathrm{k}=1,2$, ..., $\mathrm{c}$ dan $\mathrm{j}=1,2, \ldots, \mathrm{m}$

$$
\mathrm{V}_{\mathrm{kj}}=\frac{\sum_{i=1}^{n}\left(\left(\mu_{i k}\right)^{w} * X_{i j}\right)}{\sum_{i=1}^{n}\left(\mu_{i k}\right)^{w}}
$$

5. Hitung fungsi objektif pada iterasi ke-t, $P_{t}$

$$
\mathrm{P}_{\mathrm{t}}=\sum_{i=1}^{n} \sum_{k=1}^{c}\left[\left(\sum_{j=1}^{m}\left(X_{i j}-V_{k j}\right)^{2}\right)\left(\mu_{i k}\right)^{w}\right]
$$

6. Perbaiki derajat keanggotaan setiap data pada setiap cluster (Perbaiki matriks partisi), sebagai berikut:

$$
\mu_{i k}=\frac{\left[\sum_{j=1}^{m}\left(X_{i j}-V_{k j}\right)^{2}\right]^{\frac{-1}{w-1}}}{\sum_{k=1}^{c}\left[\sum_{j=1}^{m}\left(X_{i j}-V_{k j}\right)^{\frac{-1}{w-1}}\right.}
$$

$$
\text { dengan } \mathrm{i}=1,2, \ldots, \mathrm{n} \text { dan } \mathrm{k}=1,2, \ldots \mathrm{c}
$$

7. Cek kondisi berhenti:

- Jika: $\left(\left|\mathrm{P}_{\mathrm{t}}-\mathrm{P}_{\mathrm{t}-1}\right|<\xi\right)$ atau ( $>$ MaxIter) maka berhenti.

- Jika tidak: $\mathrm{t}=\mathrm{t}+1$, ulangi langkah 4 .

Data sample warna kulit yang berupa nilai RGB dilakukan pengelompokan menjadi beberapa kelompok sehingga diperoleh kelompok tangan yang menjadi target dalam penelitian ini. Beberapa sample warna kulit adalah sebagai berikut:

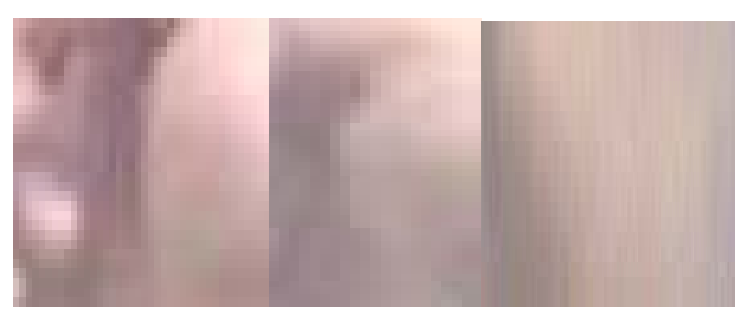

\section{Gambar 2. Sample warna kulit tangan}

\section{Integral Proyeksi}

Warna kulit tangan yang teridentifikasi, selanjutnya harus dilakukan pengenalan bentuk pola tangannya. Bentuk pola tangan menunjuk, terlebih dulu dilakukan ektrasi ciri dengan integral proyeksi.Integral proyeksi merupakan salah satu teknik ekstraksi ciri dari pola gambar dengan mengetahui besarnya itensitas dari piksel pada lokasi $(\mathrm{x}, \mathrm{y})$ sehingga untuk melakukan ekstraksi ciri dari pola dilakukan secara vertikal dan horisontal. Integral proyeksi secara vertikal $\operatorname{IPF}_{\mathrm{v}}(\mathrm{x})$ dan integral proyeksi 
horisontal $\mathrm{IPF}_{\mathrm{h}}(\mathrm{y})$ dari suatu intentitas $\mathrm{I}(\mathrm{x}, \mathrm{y})$ pada interval $\left[\mathrm{y}_{1}, \mathrm{y}_{2}\right]$ dan $\left[\mathrm{x}_{1}, \mathrm{x}_{2}\right]$ dapat dijabarkan sebagai berikut:

$$
\begin{aligned}
& \operatorname{IPF}_{v}(x)=\int_{y_{1}}^{y_{2}} I(x, y) d y \\
& I P F_{h}(y)=\int_{x_{1}}^{x_{2}} I(x, y) d x
\end{aligned}
$$

Selain itu integral proyeksi secara vertikal dan horisontal bisa digunakan nilai rata-ratanya seperti dijabarkan sebagai berikut:

$$
\begin{aligned}
& \operatorname{IPF}_{v}(x)=\frac{1}{\left(y_{2}-y_{1}\right)} \int_{y_{1}}^{y_{2}} I(x, y) d y \\
& \operatorname{IPF}_{h}(y)=\frac{1}{\left(x_{2}-x_{1}\right)} \int_{x_{1}}^{x_{2}} I(x, y) d x
\end{aligned}
$$

Dari ekstraksi dengan integral proyeksi akan diperoleh beberapa sample ektrasi ciri dari pola tangan menunjuk,sehingga dengan menggunakan rule base, berdasarkan nilai minimum dan maksimum dari masing-masing ektrasi ciri, maka identifikasi isyarat tangan akan dapat diperoleh.

\section{Learning Vektor Quantization (LVQ)}

Hasil pergerakan tangan yang dinamik menghasilkan suatu pola tulisan angka (virtual hand writing). Pola angka 1 sampai 6 tersebut dilakukan identifikasi dengan Learning Vektor Quantization (LVQ) sebagai perintah pendendali robot secara jarak jauh. LVQ adalah suatu metode neural network untuk melakukan pembelajaran pada lapisan kompetitif yang terawasi. Suatu lapisan kompetitif akan secara otomatis belajar untuk menklasifikasikan vektorvektor input. Kelas-kelas yang didapatkan sebagai hasil dari lapisan kompetitif ini hanya tergantung pada jarak antara vektor-vektor input $[8,14]$. Jika 2 vektor input mendekati sama, maka lapisan kompetitif akan meletakan kedua vektor input tersebut ke dalam kelas yang sama. Arsitektur LVQ seperti pada Gambar 4.

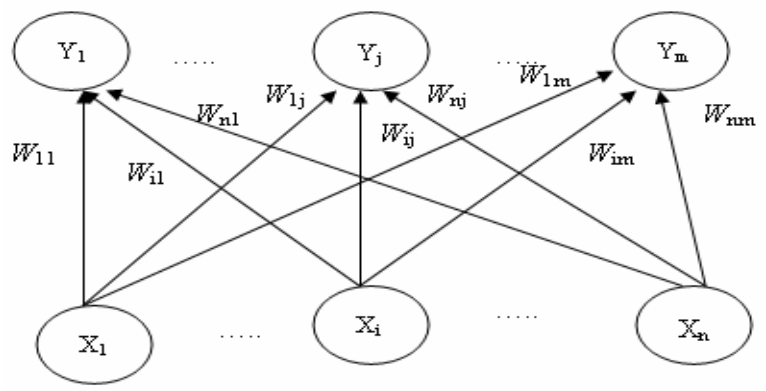

Gambar 4. Arsitektur LVQ Neural Net

\section{ANALISIS HASIL DAN IMPLEMENTASI}

\section{Deteksi Pergerakan}

Yang pertama dilakukan dalam penelitian ini, obyek yang bergerak yang akan menjadi dasar penelitian karena isyarat tangan yang akan diidentifikasi nantinya isyarat tangan yang bergerak. Bila ada obyek bergerak baik berupa tangan atau obyek yang lainnya maka perubahan dari piksel saat itu dengan piksel sebelumnya akan diperoleh suatu nilai yang menjadi deteksi pergerakan suatu obyek. Secara visual obyek yang bergerak dapat dilihat seperti pada Gambar 5.

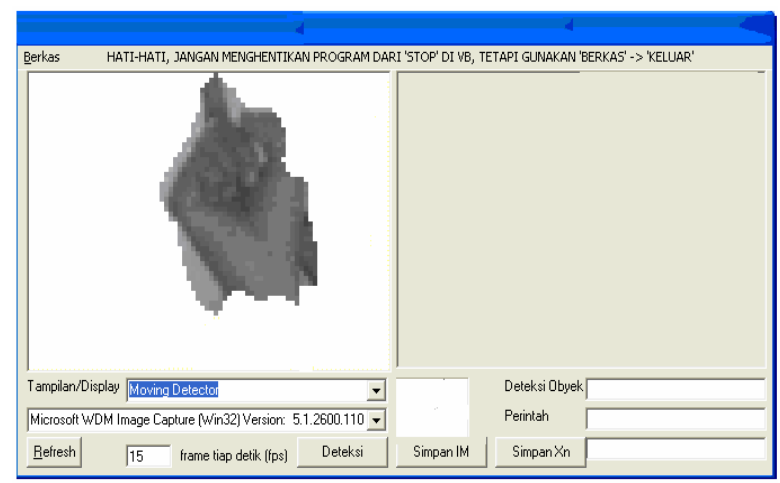

\section{Gambar 5. Deteksi Obyek Bergerak}

Secara visual pada Gambar 5, obyek yang tidak bergerak tidak terlihat dalam web kamera karena dianggap bukan target obyek, akan tetapi untuk obyek yang bergerak seperti obyek tangan pada Gambar 5 dapat diidentifikasi pergerakannya. Akurasi deteksi pergerakan obyek berdasarkan kecepatan pergerakan dengan banyaknya obyek yang bisa ditangkap oleh kamera, tabel deteksi pergerakan seperti dalam Tabel 1.

Tabel 1. Deteksi pergerakan

\begin{tabular}{|lcc|c|}
\hline No & $\begin{array}{c}\text { KecepatanGerak } \\
\text { (detik) }\end{array}$ & \multicolumn{2}{c|}{$\begin{array}{c}\text { Prosentase Deteksi } \\
\text { (\%) } \\
\text { Obyek Gerak } \\
\text { Obyek Diam (Latar } \\
\text { Belakang) }\end{array}$} \\
\hline 1. & 0.5 & 64.982 & 35.0180 \\
2. & 0.5 & 69.7246 & 30.2754 \\
3. & 0.5 & 60.8357 & 39.1643 \\
4. & 0.5 & 54.2782 & 35.5218 \\
5. & 0.5 & 68.2991 & 31.7309 \\
6. & 1 & 89.2057 & 10.7943 \\
7. & 1 & 86.7035 & 13.2965 \\
8. & 1 & 92.6609 & 17.3391 \\
9. & 1 & 90.3074 & 19.6926 \\
10. & 1 & 96.5197 & 13.4803 \\
11. & 1.5 & 70.5831 & 29.417 \\
12. & 1.5 & 69.5993 & 30.4007 \\
13. & 1.5 & 63.5222 & 36.4778 \\
14. & 1.5 & 57.8848 & 42.1152 \\
15. & 1.5 & 61.3349 & 38.6651 \\
16. & 2 & 44.8604 & 55.1396 \\
17. & 2 & 40.5524 & 59.4476 \\
18. & 2 & 40.0362 & 59.9638 \\
19. & 2 & 47.9164 & 52.0836 \\
20 & 2 & 51.4935 & 48.5065 \\
\hline
\end{tabular}


Dari Tabel 1, maka rata-rata 91.07944\% dalam kecepatan waktu 1 detik, obyek yang bergerak dapat ditangkap dalam kamera dengan baik dan rata-rata $63.62392 \%$ obyek yang bergerak dapat dideteksi dalam waktu 0.5 detik, $64.58486 \%$ rata-rata obyek yang bergerak dalam 1.5 detik dapat ditangkap pergerakkannya, dan $44.9778 \%$ rata-rata obyek yang bergerak dalam 2 detik dapat tertangkap pergerakannya oleh kamera. Hal ini bisa disebabkan oleh pengaruh kamera digital yang dipergunakan. Sedangkan secara grafik deteksi pergerakan dari Tabel 1 dapat dilihat pada Gambar 6.

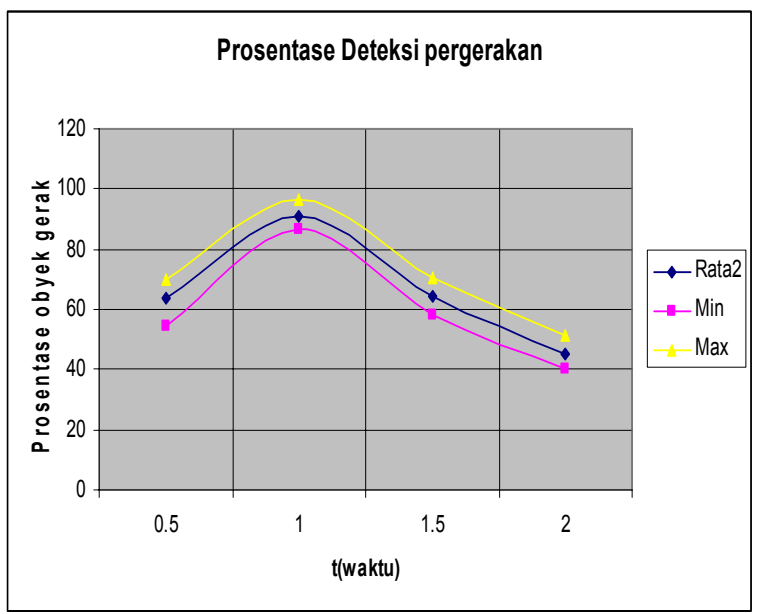

\section{Gambar 6. Grafik deteksi pergerakan}

\section{Deteksi warna kulit}

Obyek yang bergerak didepan aplikasi yang dibangun tidak hanya tangan sehingga setelah mendeteksi obyek yang bergerak, maka untuk mengetahui obyek tangan, dalam penelitian ini digunakan kulit tangan sebagai segmentasi obyek tangan.Berdasarkan sampel kulit tangan dan bukan kulit tangan, dilakukan cluster menggunakan Fuzzy C-Mean Clustering untuk membedakan kulit tangan dan bukan tangan. Untuk mengetahui obyek yang dideteksi dekat dengan cluster tertentu maka digunakan ecluidean sebakai ukuran kesamaan. Dalam pengujian dilakukan pada semua obyek yang dianggap bukan kulit dan semua obyek yang dianggap kulit tangan, sehingga prosentasi tiap piksel RGB yang termasuk cluster kulit dapat diukur [15]. Berdasarkan hasil percobaan maka untuk mewakili jumlah cluster yang lain dalam paper ini dibahas untuk jumlah cluster sebanyak 5 diperoleh sebagai berikut:

\section{$\underline{\text { Jumlah Cluster } \mathrm{n}=\mathbf{5}}$}

Centroid Cluster untuk komposisi nilai RGB adalah sebagai berikut:

\begin{tabular}{lrll} 
Variabel & \multicolumn{1}{c}{$\mathrm{R}$} & \multicolumn{1}{c}{$\mathrm{G}$} & \multicolumn{1}{c}{$\mathrm{B}$} \\
\hline Cluster 1: & 150.0985 & 77.2377 & 151.7932 \\
Cluster 2: & 150.7088 & 146.7710 & 153.8652 \\
Cluster 3: & 96.9108 & 98.3328 & 104.7871 \\
Cluster 4: & 248.0088 & 249.6473 & 248.0593 \\
Cluster 5: & 127.7786 & 129.8867 & 135.5949
\end{tabular}

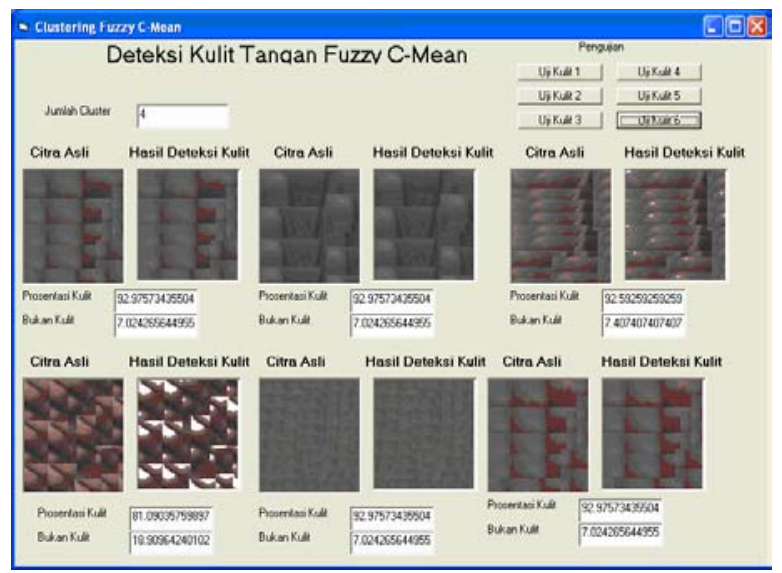

\section{Gambar 7. Uji kulit pada 5 Cluster}

Dari hasil pengujian obyek bukan kulit, kebenaran rata-rata $100 \%$ termasuk cluster bukan kulit dan $0 \%$ salah masuk ke cluster kulit. Sedangkan dari hasil pengujian obyek kulit maka rata-rata kebenaran masuk pada cluster kulit $90.2834 \%$ dan $9.6956 \%$ salah cluster.

Hasil cluster tersebut diaplikasikan untuk membedakan mana kulit dan bukan kulit sehingga segmetasi obyek dapat diperoleh, secara visual terlihat pada Gambar 8.

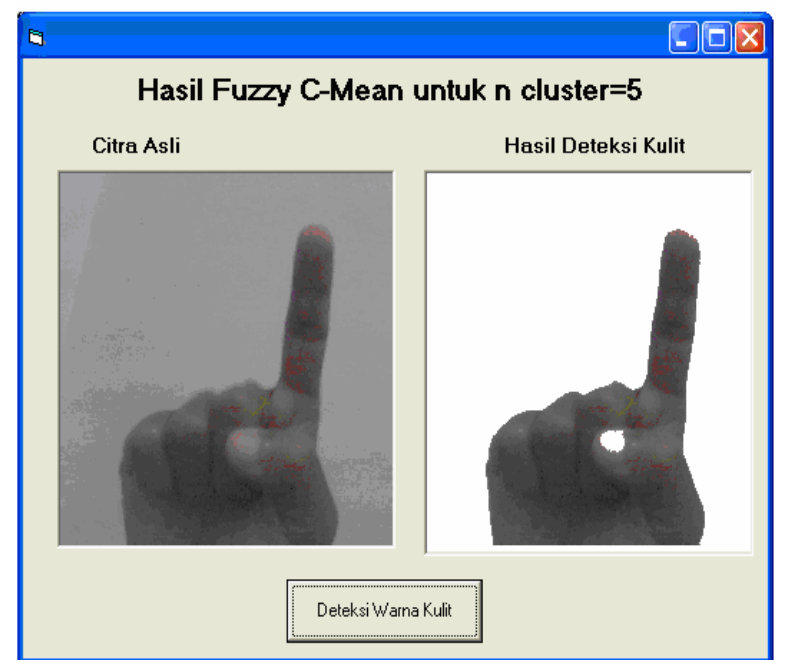

\section{Gambar 8. Uji segmentasi kulit tangan}

Secara grafik hasil pengujian skin deteksi menggunakan jumlah cluster 5 dapat dilihat pada Gambar 9. 


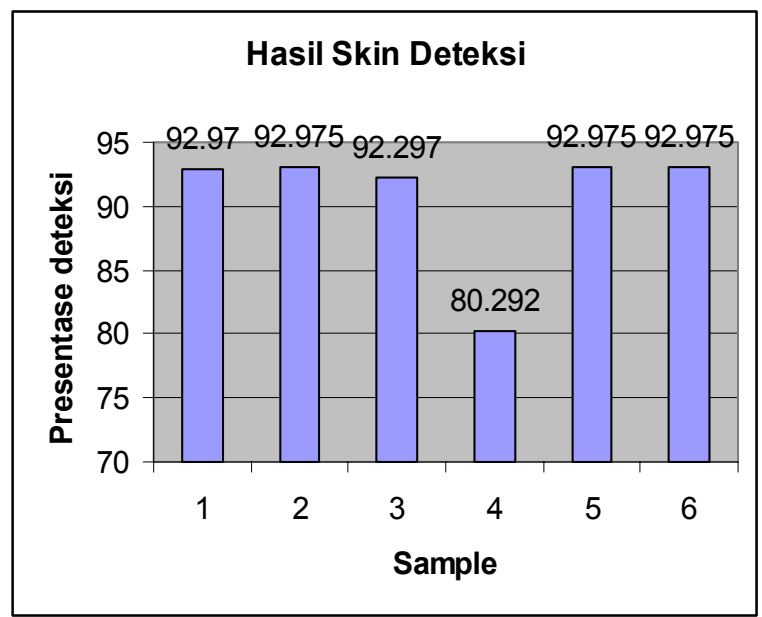

Gambar 9. Hasil skin deteksi cluster $=5$

\section{Deteksi pola bentuk tangan}

Dalam penelitian ini, obyek yang tertangkap oleh web camera yang termasuk warna kulit dimungkinkan juga ada obyek yang lain, yang dekat dengan kulit tangan. Sehingga harus dibedakan obyek tangan tidak hanya berdasarkan warna kulitnya saja tetapi juga berdasarkan pola bentuk tangan. Menggunakan integral proyeksi pola bentuk tangan untuk tangan bertelunjuk dapat dilihat pola bentuk gambarnya baik yang dihasilkan secara integral proyeksi secara vertikal maupun secara horisontal. Hasil secara visual menggunakan integral proyeksi dapat dilihat pada Gambar 10.

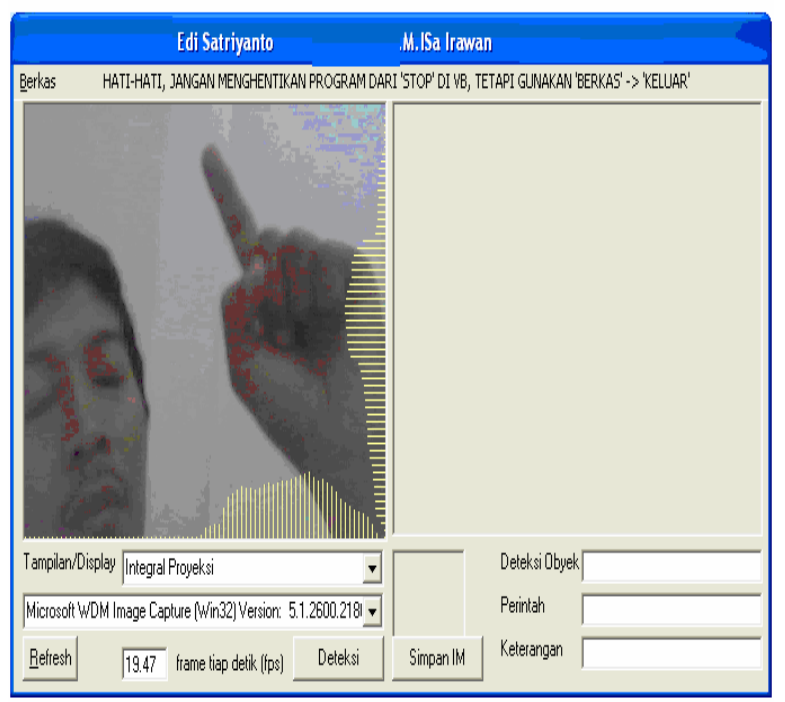

Gambar 10. Integral proyeksi pada pola tangan bertelunjuk.

Berdasarkan Tabel 2, 86.67\% deteksi pola tangan sesuai dengan target yang diharapkan.
Tabel 2. Hasil identifikasi pola tangan

\begin{tabular}{cc|c|c}
\hline No.Sampel & X1 & X2 & X3 \\
\hline 1 & 2 & 2 & 10 \\
2 & 3 & 3 & 10 \\
3 & 3 & 2 & 9 \\
4 & 2 & 2 & 10 \\
5 & 2 & 2 & 15 \\
6 & 2 & 4 & 10 \\
7 & 2 & 2 & 9 \\
8 & 2 & 2 & 11 \\
9 & 2 & 2 & 10 \\
10 & 3 & 4 & 10 \\
\hline Minimum & 2 & 2 & 9 \\
Maksimum & 3 & 4 & 15 \\
Ratarata & 2.3 & 2.5 & 10 \\
\hline
\end{tabular}

Deteksi pola gambar pergerakan tangan sebagai pengendali robot

Hasil identifikasi pergerakan tangan yang dimaksud menghasilkan suatu pola gambar angka yang ditampilkan dalam layar monitor sebagai virtual hand writing, hasil dari virtual hand writing dilakukan identifikasi. Hasil secara visual dapat dilihat pada Gambar 11.

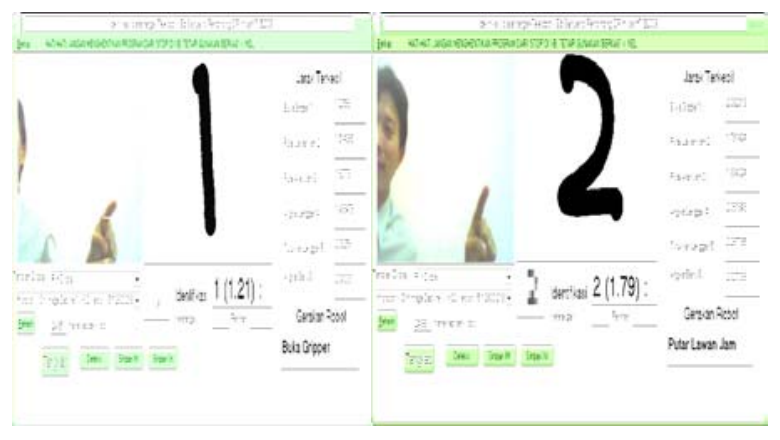

Gambar 11. Virtual hand writing sebagai pola gambar angka 1 dan 2

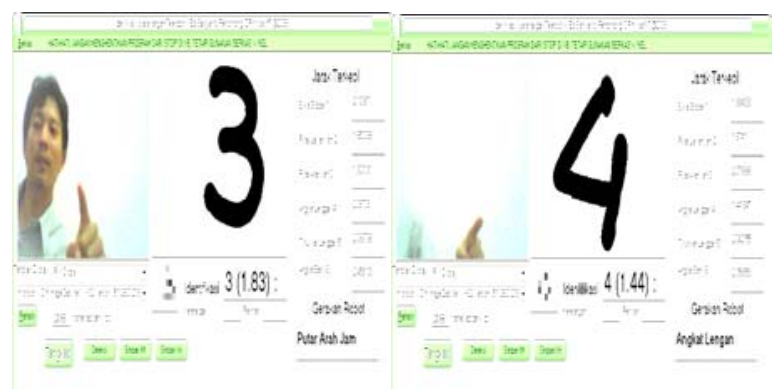

Gambar 12. Virtual hand writing sebagai pola gambar angka 3 dan 4 


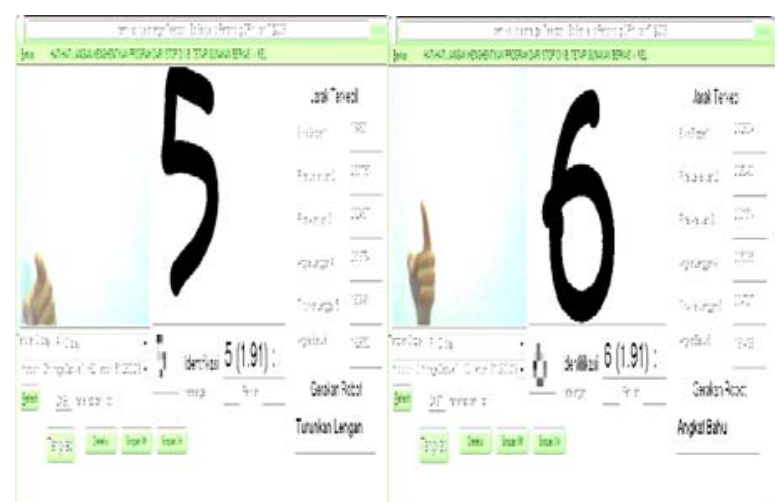

Gambar 13. Virtual hand writing sebagai pola gambar angka 5 dan 6

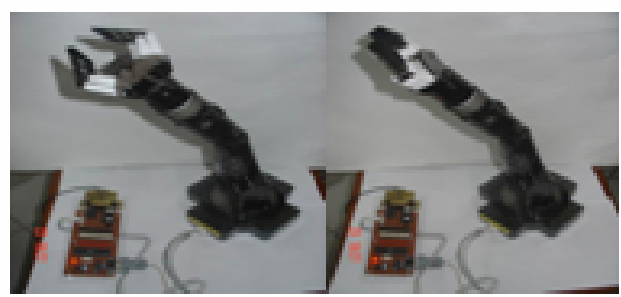

(a)

(b)

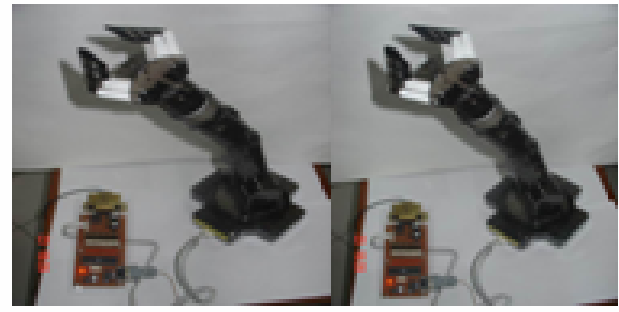

(c)

(d)

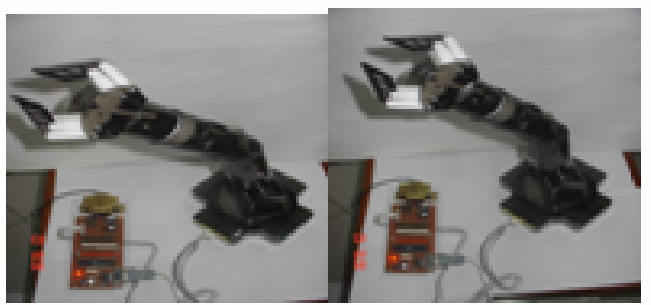

(o)

(f)

Gambar 14. Hasil gerakan robot penelitian (a) membuka (b) memutar pergelangan tangan berlawan jarum jam (c) memutar pergelangan tangan searah jarum jam (d) mengangkat lengan (e) menurunkan lengan (f) Mengangkat bahu.

Berdasarkan pengujian terhadap angka yang belum dikenali, seperti dalam Tabel 3 .
Tabel 3. Pengujian terhadap pola angka

\begin{tabular}{c|c|c|ccc|c|cc}
\hline Pola & \multicolumn{9}{|c}{ Jarak } & Jarak & $\begin{array}{c}\text { Hasil } \\
\text { Sample }\end{array}$ & 1 & 2 & 3 & 4 & 5 & 6 & Terdekat & Pengenalan \\
\hline Angka 1 & 1.128 & 1.485 & 1.567 & 1.814 & 2.095 & 2.145 & 1 & Satu(Benar) \\
Angka 1 & 1.168 & 2.04 & 2.206 & 2.287 & 2.368 & 2.668 & 1 & Satu(Benar) \\
Angka 1 & 1.257 & 1.763 & 1.793 & 1.655 & 2.166 & 2.172 & 1 & Satu(Benar) \\
Angka 1 & 1.206 & 1.514 & 1.628 & 1.489 & 2.083 & 2.040 & 1 & Satu(Benar) \\
Angka 2 & 2.146 & 1.606 & 2.081 & 2.111 & 2.275 & 2.577 & 2 & Dua(Benar) \\
Angka 2 & 2.082 & 1.791 & 1.884 & 2.062 & 2.268 & 2.327 & 2 & Dua(Benar) \\
Angka 2 & 2.225 & 1.935 & 2.389 & 2.474 & 2.464 & 2.651 & 2 & Dua(Benar) \\
Angka 2 & 2.383 & 1.820 & 2.297 & 2.417 & 2.504 & 2.497 & 2 & Dua(Benar) \\
Angka 3 & 2.487 & 2.128 & 1.897 & 2.489 & 2.139 & 2.690 & 3 & Tiga(Benar) \\
Angka 3 & 2.134 & 1.950 & 1.830 & 2.067 & 2.399 & 2.459 & 3 & Tiga(Benar) \\
Angka 3 & 2.259 & 1.765 & 1.477 & 2.111 & 1.666 & 2.283 & 3 & Tiga(Benar) \\
Angka 3 & 2.190 & 2.188 & 2.147 & 2.251 & 2.460 & 2.636 & 3 & Tiga(Benar) \\
Angka 4 & 1.994 & 1.874 & 2.076 & 1.441 & 1.342 & 2.057 & 4 & Empat(Benar) \\
\hline
\end{tabular}

Seperti dari hasil pengujian tersebut, maka ada $79.2 \%$ pola angka dapat dikenali sesuai dengan target yang dimaksud., sehingga dapat digunakan sebagai perintah untuk mengendalikan robot secara jarak jauh. Hasil aplikasi pada robot untuk perintah pola gerakan tangan dalam angka tiga, robot melakukan gerakan memutar pergelangan searah jarum jam.

\section{KESIMPULAN}

Berdasarkan pada hasil analisis dan implementasi, dapat disimpulkan sebagai berikut:

1. Hasil deteksi pergerakan obyek (moving detection) dalam area kamera yang mampu dideteksi dengan baik adalah waktu 1 detik, sebesar 91.07944\%. Untuk waktu yang lebih kecil dari 1 detik atau lebih besar dari 1 detik, tingkat keberhasilannya bertambah rendah.

2. Hasil deteksi warna kulit menggunakan Fuzzy CMean(FCM) pada jumlah cluster 5, mampu melakukan identifikasi warna kulit sebesar kulit 90.2834\% sedangkan dalam membedakan latar obyek dapat melakukan identifikasi 100\% dengan latar obyek yang mendekati warna putih, makin sedikit jumlah cluster maka latar belakang obyek makin sedikit variasi yang mampu diidentifikasi, sebaliknya makin banyak jumlah cluster maka makin banyak obyek masuk ke cluster latar obyek.

3. Hasil identifikasi pola tangan, dimana ekstraksi cirinya digunakan integral proyeksi, dengan metode rule base dapat diidentifikasi $86.67 \%$.

4. Hasil gerakan tangan yang telah diidentifikasi menghasilkan virtual hand writing, berupa pola gambar angka 1 sampai 6. Dengan LVQ, setelah dilakukan pengujian $79.2 \%$ pola angka dapat dikenali sesuai dengan target

5. Robot dapat dikendalikan secara jarak jauh, sesuai dengan pola pergerakan isyarat tangan yang berupa virtual hand writing sebagai perintah yang telah ditentukan. 


\section{DAFTAR PUSTAKA}

1. Naga Jyothi, D., Multi-View Technique for 3-D Robotic Object Recognition System Using NeuroFuzzy Method, Map India Conference, 2004.

2. Munir, Rinaldi, Pengolahan Citra Digital dengan Pendekatan Algoritmik, Informatika Bandung, Agustus 2004.

3. Satriyanto, E., D. Pramadianto, dan R. Ayuningtyas, Identifikasi Bahasa Isyarat untuk Memandu Parkir Pesawat, EEPIS ITS, 2002.

4. Satriyanto, E., D. Pramadianto, dan E. Purwantini, Identifikasi bahasa Isyarat Tangan Sebagai Media Komunikasi Tuna Wicara, EIS-EEPS, 2000.

5. Symeonidis, K., Gesture Recognition Using Neural Networks, Technical Report, School of Electronic and Electrical Engineering, August 2000.

6. Wachs, Juan, U. Kartoun, H. Stern, and Y. Edan, Real-Time Hand Gesture Telerobotic System Using the Fuzzy C-Mean Clustering Algorithm, Technical Reports Department of Industrial Engineering and Management Ben-Gurion University of the Negev, Israel, 2004.

7. Feris, Rogerio Schmidt, Teofilo Emídio de Campos, Roberto and Marcondes Cesar Junior, Detection and Tracking of Facial Features in Video Sequences, MICAI-2000.

8. Cutler, Ross, and M. Turk, View-based Interpretation of Real Time Optical Flow for Gesture Recoqnition, Technical Reports, University of Maryland, USA, 2004.
9. Cutler, Ross and Matthew Turk, View-Based Interpretation of Real-Time for Gesture Recognition, Microsoft Reasearch Redmond, Washington, 1998.

10. Billard, Aude, Yann Epars, Sylvain Calinon, Gordon Cheng, and Stefan Schaal, Discovering Optimal Imitation Strategie, Journal of Robotics and Autonomous System, vol.47:2-3, 2004.

11. Gordan, Mihaela, Costin Miron, Apostolos Georgakis, An Optimal Features Selection Strategy For Fuzzy C-Means, Application to Lip-ToSkin Discrimination, IEE-TTTC, Cluj-Napoca, Romania, May 13-15,2004.

12. Irawan, M. Isa, dan Taufik, Perancangan Protyotipe Sistem Real-Time Neuro-Fuzzy Classifier untuk Pengelompokan Kualitas Produk Gelas, Proceeding Seminar Nasional Pascasarjana ITS, Agustus 2005.

13. Calinon S, and A Billard, Stochastic Gesture Production and Recognition Model for a Humanoid Robot, Proceeding of International Conference on Intelegent Robot and System, IEEE/RSJ, September 2004.

14. Martinez-Cabeza-de-Vaca-Alajarin, Juan, TomasBalibra, Luis-Manuel, Marble Slabs Quality Classification System using Texture Recognition and Neural Network Methodology, ESANN proceeding, 1999.

15. Alon, Jonathan, Vassilis Athitsos, Quan Yuan, and Stan Sclaroff, Simultaneous Localization and Recognition of Dynamic Hand Gesture, IEEE Workshop on Motion and Video Computing, January 2005. 